\title{
Hydrogen by Deuterium Substitution in an Aldehyde Tunes the Regioselectivity by a Nonheme Manganese(III)-Peroxo Complex
}

DOI:

10.1002/anie.201905416

\section{Document Version}

Accepted author manuscript

Link to publication record in Manchester Research Explorer

Citation for published version (APA):

Barman, P., Cantu Guerra, F., Bagha, U. K., Kumar, D., Sastri, C. V., \& De Visser, S. (2019). Hydrogen by Deuterium Substitution in an Aldehyde Tunes the Regioselectivity by a Nonheme Manganese(III)-Peroxo Complex. Angewandte Chemie. https://doi.org/10.1002/anie.201905416

Published in:

Angewandte Chemie

\section{Citing this paper}

Please note that where the full-text provided on Manchester Research Explorer is the Author Accepted Manuscript or Proof version this may differ from the final Published version. If citing, it is advised that you check and use the publisher's definitive version.

\section{General rights}

Copyright and moral rights for the publications made accessible in the Research Explorer are retained by the authors and/or other copyright owners and it is a condition of accessing publications that users recognise and abide by the legal requirements associated with these rights.

\section{Takedown policy}

If you believe that this document breaches copyright please refer to the University of Manchester's Takedown Procedures [http://man.ac.uk/04Y6Bo] or contact uml.scholarlycommunications@manchester.ac.uk providing relevant details, so we can investigate your claim.

\section{OPEN ACCESS}




\title{
Hydrogen by Deuterium Substitution in an Aldehyde Tunes the Regioselectivity by a Nonheme Manganese(III)-Peroxo Complex ${ }^{\star \star}$
}

\author{
Prasenjit Barman, ${ }^{[\mathrm{a}]}$ Fabián G. Cantú Reinhard, ${ }^{[\mathrm{b}]}$ Umesh Kumar Bagha, ${ }^{[\mathrm{a}]}$ Devesh Kumar, ${ }^{[\mathrm{c}]}$ Chivukula \\ V. Sastri ${ }^{*[a]}$ and Sam P. de Visser ${ }^{*[b]}$
}

\begin{abstract}
Mononuclear nonheme Mn(III)-peroxo complexes are important intermediates in biology, and for instance take part in the oxygen activation by Photosystem II. Herein, we present work on two novel isomeric biomimetic side-on Mn(III)-peroxo intermediates with bispidine ligand system and reactivity patterns with aldehydes. The complexes are characterized with UV-Visible and mass spectrometric techniques and reaction rates with cyclohexane carboxaldehyde (CCA) have been measured. The reaction gives an unusual regioselectivity switch from aliphatic to aldehyde hydrogen atom abstraction upon deuteration of the substrate leading to the corresponding carboxylic acid product for the latter, while the former gives a deformylation reaction. Mechanistic details are established from kinetic isotope effect studies alongside density functional theory calculations. Thus, replacement of $\mathrm{C}-\mathrm{H}$ by $\mathrm{C}-\mathrm{D}$ raises the hydrogen atom abstraction barriers and enables a regioselectivity switch to a competitive pathway that is slightly higher in energy.
\end{abstract}

In general, dioxygen in nature is mostly inert and will not react with substrates directly. In order to activate oxygen to its more reactive form, enzymes bind dioxygen on a transition metal center and through the use of either protons/electrons or a cosubstrate convert it into an high-valent metal-oxo, metal-peroxo, metal-hydroperoxo or metal-superoxo species. ${ }^{[1]}$ These intermediates are responsible for the biological transformations of substrates in enzymes. ${ }^{[2]}$ As the active oxygen species in enzymes are short-lived and highly reactive they are difficult to study experimentally. Manganese ions are present in the active site structure of numerous enzymes that utilize molecular oxygen, and are involved in harmful superoxide detoxification, decomposition of hydrogen peroxide, and water splitting. ${ }^{[3]}$ Most

[a] Dr. P. Barman, Mr. U.K. Bagha, Dr. C.V. Sastri

Department of Chemistry

Indian Institute of Technology Guwahat

Guwahati (Assam), India, 781039

sastricv@iitg.ernet.in

[b] Dr F.G. Cantú Reinhard, Dr. S.P. de Visser

Manchester Institute of Biotechnology and School of Chemical

Engineering and Analytical Science

The University of Manchester, 131 Princess Street, Manchester M1

7DN, United Kingdom

sam.devisser@manchester.ac.uk

[c] Dr. D. Kumar

Department of Applied Physics

School of Physical Sciences

Babasaheb Bhimrao Ambedkar University

Lucknow, India, 226025

dkclcre@yahoo.com

[**] Research support was provided by the Department of Science and Technology (SERB), India (EMR/2014/000279) to CVS. SdV and CVS thank the British Council for a UK-India Research Initiative grant (DST/INT/UK/P-151/2017). FC thanks the Conacyt Mexico for a studentship. DK acknowledges financial support from the Department of Biontechnology, New Delhi (BT/PR14510/BID/07/334/2010)

Supporting information for this article is given via a link at the end of the document. of these enzymes include either a manganese-oxo, manganesesuperoxo or manganese-peroxo structure as active intermediate in their catalytic cycle; however, these structures are short-lived and few have been characterized experimentally. As a consequence, biomimetic models have been created of manganese(III)-peroxo complexes that have ligand features of the enzymatic structures but lack the protein surrounding. ${ }^{[4]}$

A number of biomimetic manganese(III)-peroxo complexes have been synthesized and characterized with spectroscopic methods. ${ }^{[5]}$ In addition, for some of those the reactivity against substrates was tested. ${ }^{[6]}$ Thus, in general side-on manganese(III)-peroxo reacts via nucleophilic pathways, for instance, through deformylation of aldehydes. ${ }^{[7]}$ Several of these metal-peroxo complexes have shown unusual reactivity patterns, whereby, for instance, aldehydes were converted into alkanes in the presence of a switchable $\mathrm{H}$-atom donor. ${ }^{[8]}$ Recent work of our groups implicated aldehyde deformylation of 2phenylpropionaldehyde (2-PPA) to start with an initial and rate determining hydrogen atom abstraction followed by keto-enol tautomerization and a deformylation reaction and confirmed the electrophilic nature of these oxidants. ${ }^{[9]}$ Clearly, side-on manganese(III)-peroxo complexes show a versatile reactivity pattern with a variety of substrates that is poorly understood which encouraged us to look deeper into their reactivity with substrates.

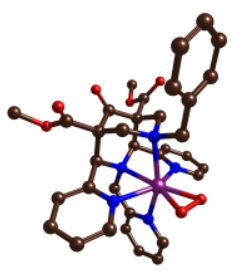

$\left[\mathrm{Mn}^{\prime \prime \prime}\left(\mathrm{O}_{2}\right)\left(\mathrm{L}^{1}\right)\right]^{+}$

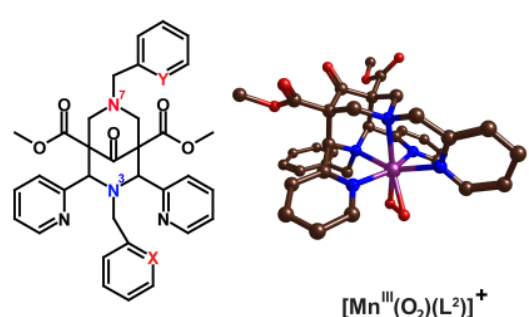

$\left[\mathrm{Mn}{ }^{\prime \prime \prime}\left(\mathrm{O}_{2}\right)\left(\mathrm{L}^{2}\right)\right]^{+}$
Figure 1. Oxidants investigated in this work. DFT optimised structures of $\left[\mathrm{Mn}^{\mathrm{III}}\left(\mathrm{O}_{2}\right)\left(\mathrm{L}^{1}\right)\right]($ left, $\mathrm{X}=\mathrm{N}, \mathrm{Y}=\mathrm{C})$, and $\left[\mathrm{Mn}^{\mathrm{III}}\left(\mathrm{O}_{2}\right)\left(\mathrm{L}^{2}\right)\right]$ (right, $\left.\mathrm{X}=\mathrm{C}, \mathrm{Y}=\mathrm{N}\right)$.

In this work, we report the synthesis and characterization of two side-on manganese(III)-peroxo complexes (Figure 1) with a pentadentate N5 bispidine ligand backbone, namely $\left[\mathrm{Mn}^{\prime \prime \prime}\left(\mathrm{O}_{2}\right)\left(\mathrm{L}^{1}\right)\right]^{+}(\mathbf{1})$ and $\left[\mathrm{Mn}^{\prime \prime \prime}\left(\mathrm{O}_{2}\right)\left(\mathrm{L}^{2}\right)\right]^{+}(\mathbf{2})$ with $\mathrm{L}^{1}=$ dimethyl-2,4di(2-pyridyl)3-(pyridin-2-ylmethyl)-7-benzyl-3,7-diaza-

bicyclo[3.3.1] nonan-9-one-1,5-dicarboxylate) and $L^{2}=$ dimethyl 2,4-di(2-pyridyl)-3-benzyl-7-(pyridin-2-ylmethyl)-3,7-

diazabicyclo[3.3.1] nonan-9-one-1,5-dicarboxylate). ${ }^{[9-11]}$ Treatment of a colorless solution of the manganese(II) precursor with 10 equivalents of $\mathrm{H}_{2} \mathrm{O}_{2}$ and triethylamine (TEA; 2.5 equivalents) in $\mathrm{CH}_{3} \mathrm{CN}$ at $15{ }^{\circ} \mathrm{C}$ results in the formation of a blue and brown intermediate for $\mathbf{1}$ and $\mathbf{2}$, respectively. ${ }^{[10]}$ The identity of complexes $\mathbf{1}$ and $\mathbf{2}$ was confirmed from ultraviolet-visible absorption spectroscopy (UV-Vis) and electrospray ionizationmass spectrometry (ESI-MS) studies. ${ }^{[9,10]}$ Few metal-peroxo oxidants have been reported that react via hydrogen atom abstraction reactions, therefore, we decided to extend our work to other substrates to evaluate the factors responsible for such 
unique reaction pathways. As such we investigated the reactivity of complexes $\mathbf{1}$ and $\mathbf{2}$ with cyclohexane carboxaldehyde (CCA) as it is a classical substrate used in several reactivity studies by manganese(III)-peroxo complexes and generally gives cyclohexanone as product. ${ }^{[7 d, 12]}$

Upon addition of 40 equiv. of $\mathrm{CCA}$ to 1 in $\mathrm{CH}_{3} \mathrm{CN}$ at $15^{\circ} \mathrm{C}$, the intermediate decayed immediately and led to cyclohexanone as product (Figure 2). The pseudo-first-order rate constant of the decay of 1 increased linearly with increasing CCA concentration, thus enabling us to determine the second-order rate constant of the reaction: $k_{2}=0.064 \mathrm{M}^{-1} \mathrm{~s}^{-1}$ (Figure 2b). By contrast, the second-order rate constant for the oxidation of CCA by 2 gave a rate constant of $k_{2}=0.291 \mathrm{M}^{-1} \mathrm{~s}^{-1}$. The rate changes between 1 and $\mathbf{2}$ are similar to those reported previously for the oxidation of 2-PPA. ${ }^{[9]}$

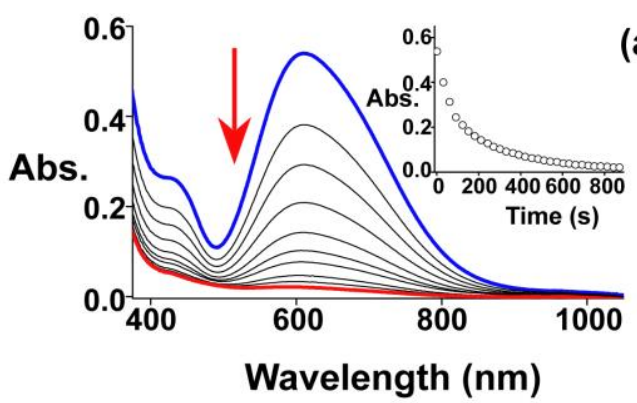

(a)

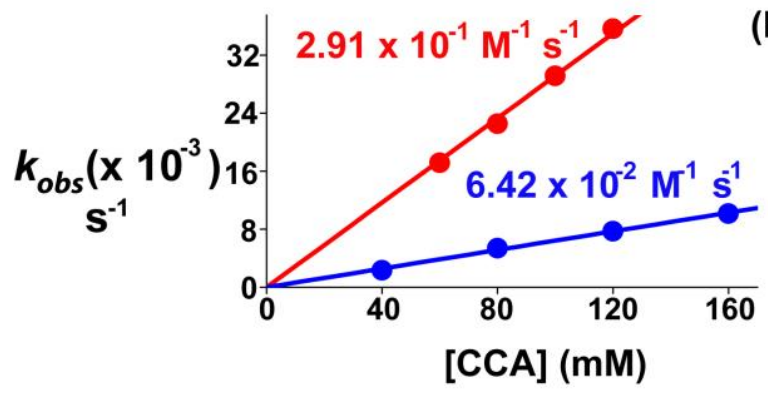

(b)

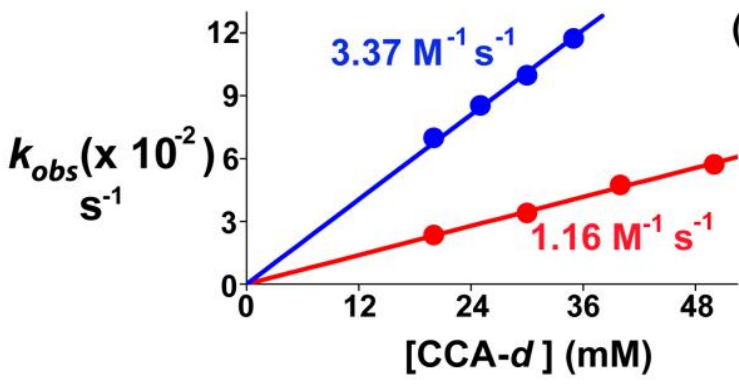

(c)

Figure 2. Kinetic studies for the reaction of 1 and 2 with CCA: a) UV-Vis spectral changes of $1(2 \mathrm{mM})$ upon addition of CCA $(120 \mathrm{mM})$ in the presence of TEA $(5 \mathrm{mM})$ and hydrogen peroxide $(20 \mathrm{mM})$ in $\mathrm{CH}_{3} \mathrm{CN}$ at $15^{\circ} \mathrm{C}$. Inset shows the time course of the absorbance at $605 \mathrm{~nm}$. b) Plot of $k_{\text {obs }}$ against the concentration of CCA: second-order rate constant for the reaction of $2 \mathrm{mM} 1$ (blue $\bullet$ ) and 2 (red $\bullet$ ) with various substrate concentrations in $\mathrm{CH}_{3} \mathrm{CN}$ at $15^{\circ} \mathrm{C}$ c) Plot of $k_{\text {obs }}$ against the concentration of $\alpha-\left[D_{1}\right]-C C A(\sim 90 \%$, D enriched) with $2 \mathrm{mM} 1$ and 2 in $\mathrm{CH}_{3} \mathrm{CN}$ at $15^{\circ} \mathrm{C}$ [data for $\mathbf{1}$ (blue $\bullet$ ) and 2 (red $\bullet$ ) are given.

As previous work reported a rate-determining hydrogen atom abstraction reaction, we decided to synthesize $\alpha-\left[D_{1}\right]-C C A$ and repeat the kinetics experiments with 1 and 2 (Figure 2c). Surprisingly, upon addition of 40 equiv. of $\alpha-\left[D_{1}\right]-C C A$ to 1 at $15^{\circ} \mathrm{C}$, an enhanced reaction rate as compared to CCA was observed. The second-order rate constants for the reactivity of
$\alpha$-[D $\left.D_{1}\right]$-CCA with 1 were 50 times faster when compared with parent CCA and implicated an effective $\mathrm{KIE}=0.02$. The product analysis by NMR revealed that the product for the reaction of $\alpha$ $\left[D_{1}\right]$-CCA with 1 was cyclohexane carboxylic acid (Scheme 1) rather than the expected cyclohexanone. This clearly indicates a regioselectivity switch for hydrogen atom abstraction from the $\alpha$ position of substrate to the aldehyde hydrogen atom instead. The observed second-order rate constants for the reaction of $\alpha$ $\left[D_{1}\right]$-CCA with 1 and 2 were $3.37 \mathrm{M}^{-1} \mathrm{~s}^{-1}$ and $1.16 \mathrm{M}^{-1} \mathrm{~s}^{-1}$, respectively. These observed trends are in contrast to those obtained for the reaction of $\mathbf{1}$ and $\mathbf{2}$ with 2-PPA. As far as we know, our observation of the oxidation of $\alpha-\left[D_{1}\right]-C C A$ to its corresponding acid is the first experimental evidence of a $\mathrm{Mn}$ (III)-peroxo intermediate that reacts via an electrophilic oxidation reaction. The observed oxidation rates of $\mathbf{1}$ and $\mathbf{2}$ follow a similar trend as shown previously for $\left[\mathrm{Mn}^{\mathrm{IV}}(\mathrm{O})\left(\mathrm{L}^{1}\right)\right]^{2+}$ versus $\left[\mathrm{Mn}^{\mathrm{IV}}(\mathrm{O})\left(\mathrm{L}^{2}\right)\right]^{2+} \cdot{ }^{[10]}$ This unique regioselectivity switch observed here may be the result of two competing pathways that are close in energy and whereby deuteration reverses the ordering of the transition states and hence the product distributions as seen, for instance, in the hydroxylation of ethylbenzene versus ethylbenzene-[ $\left.D_{10}\right]$ with iron(IV)-oxo
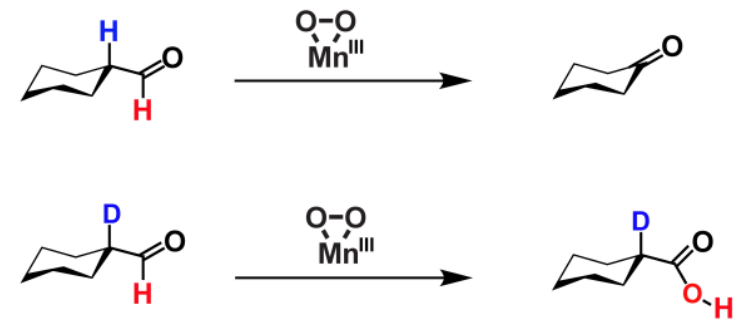

complexes. ${ }^{[13]}$

Scheme 1. Products obtained for the reaction of 1 and 2 with substrates.

In order to substantiate our hypothesis further, we synthesized 1,2-di-deuterio-cyclohexane carboxaldehyde ( $90 \%$, D enriched) $\left(1,2-\left[D_{2}\right]-C C A\right)$. Upon addition of 40 equiv. of $1,2-\left[D_{2}\right]-C C A$ to 1 in $\mathrm{CH}_{3} \mathrm{CN}$ at $15^{\circ} \mathrm{C}$, the corresponding intermediate readily decays and enabled us to follow the reaction spectroscopically. A second-order rate constant of $4.8 \times 10^{-2} \mathrm{M}^{-1} \mathrm{~s}^{-1}$ with an effective KIE of 70 were determined.

To gain insight into the regioselectivity switch and the nature of the oxidant and reactivity patterns, we decided to complement our work with a density functional theory study. Although several density functional theory methods were tested, see Supporting Information, we will focus on the B3LYP and B3LYP-D3 results in the main text only. In general, all methods predict the same trends and give analogous optimized structures. We then calculated a reactant complex ( $\mathbf{R e})$ of CCA with $\mathbf{1}$. The geometry and electronic configuration of the manganese-peroxo complex changed little upon complexation with CCA. Thereafter, two hydrogen atom abstraction pathways were investigated, namely via transition state ${ }^{5} \mathbf{T} \mathbf{S}_{\mathrm{HA} \text {,ald }}$ for hydrogen atom abstraction from the aldehyde $\mathrm{C}-\mathrm{H}$ bond and via transition state ${ }^{5} \mathbf{T S}_{\mathrm{HA}, \alpha}$ for hydrogen atom abstraction from the $\mathrm{C}^{\alpha}-\mathrm{H}$ bond of CCA. 

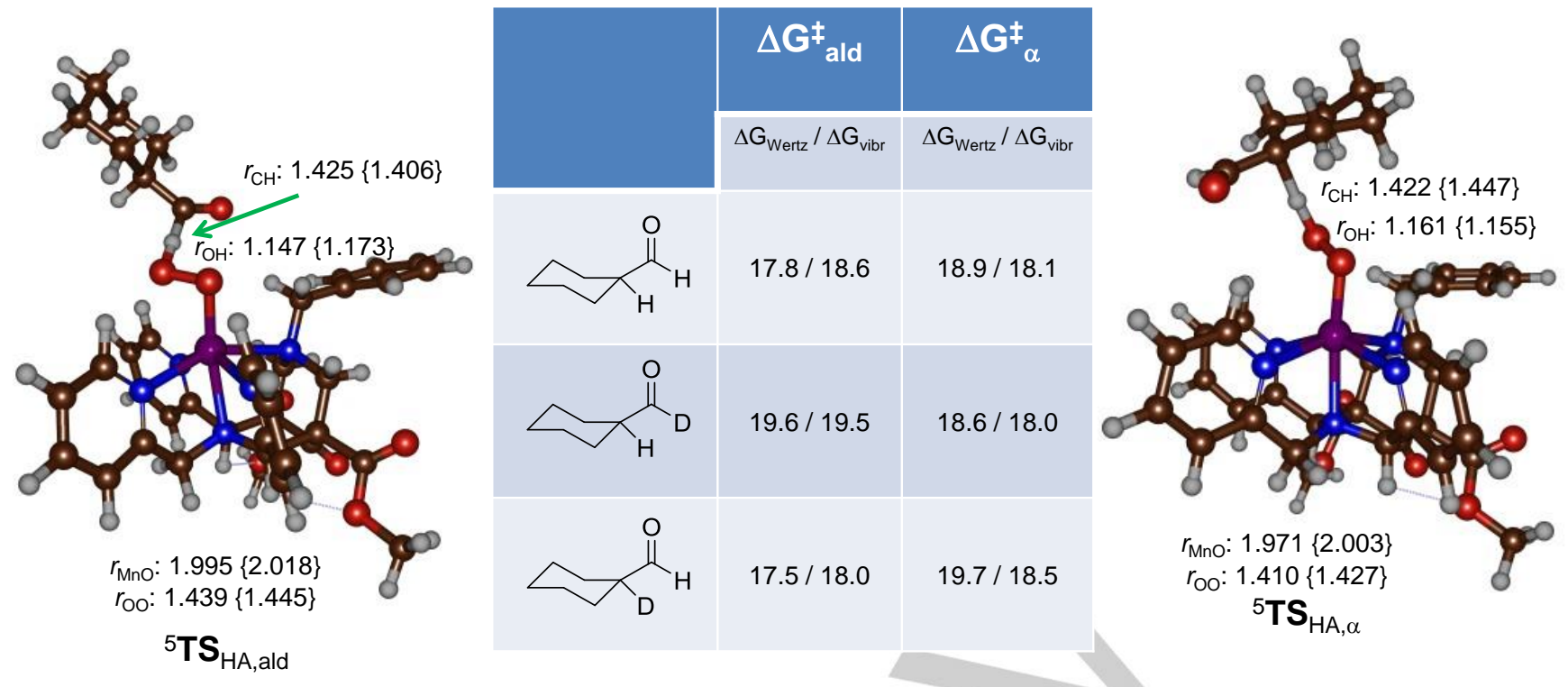

Figure 3. Hydrogen atom abstraction transition states optimized at UB3LYP/BS1 \{UB3LYP-D3/BS2\} from aldehyde group (left) and $\mathrm{C}^{\alpha}-\mathrm{H}$ bond (right) with bond lengths in angstroms. The Table gives corrected (Wertz/vibrational) free energies of activation calculated at UB3LYP/BS2//UB3LYP/BS1 level of theory for the two

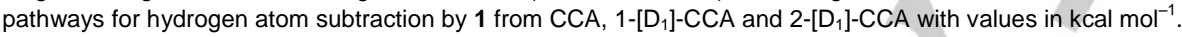

In both cases an end-on manganese-hydroperoxo with a substrate radical is formed ( $\mathbf{I}_{\mathrm{HA}, \text { ald }}$ and $\left.\mathbf{I}_{\mathrm{HA}, \alpha}\right)$ after hydrogen atom abstraction. The two hydrogen atom abstraction transition states are shown in Figure 3 and give the typical features seen before. ${ }^{[9]}$ Thus, ${ }^{5} \mathrm{TS}_{\mathrm{HA}, \text { Ald }}$ is late with a long $\mathrm{C}-\mathrm{H}$ distance of 1.425 \{1.406\} $\AA$ and a short O-H distance of 1.147 \{1.173\} $\AA$ and with the hydroperoxo group in end-on configuration as calculated at the B3LYP/BS1 \{B3LYP-D3/BS2\} level of theory. As such there is little effect of changing the basis set on the optimized geometries of the transition state structures. Although the optimized geometries have end-on features, actually an intrinsic reaction coordinate scan (Supporting Information, Figure S23), shows the structure to connect to the side-on $\mathrm{Mn}$ (III)-peroxo reactant, but upon approach of substrate to oxidant it reorients from side-on to end-on $\mathrm{Mn}(\mathrm{III})$-peroxo without an isomerization barrier. The aliphatic hydrogen atom abstraction barrier $\left({ }^{5} \mathbf{T S}_{\mathrm{HA}, \mathrm{\alpha}}\right)$ also is late with similar $\mathrm{C}-\mathrm{H}$ and $\mathrm{O}-\mathrm{H}$ distances with respect to ${ }^{5} \mathbf{T S}_{\mathrm{HA} \text {,ald }}$ with distances of $1.422\{1.447\}$ and $1.161\{1.155\} \AA$ as calculated at the B3LYP/BS1 \{B3LYP-D3/BS2\} level of theory, respectively. In general, late hydrogen atom abstraction transition states correspond to energetically high barriers, ${ }^{[14]}$ which indeed is seen for this process and matches the experimental reaction rates well.

Free energies of activation for the two reaction pathways were calculated from the Gaussian frequencies using thermal, solvent and entropic corrections to the enthalpy. As gas-phase calculated entropies tend to be overestimated with respect to experiment, ${ }^{[15]}$ we applied two entropic correction models. Firstly, we used the Wertz correction (model 1) that scales the molecular entropy of each compound $\left(\Delta \mathrm{G}_{\text {Wertz }}{ }^{\ddagger}\right)$. Secondly, the lowest entropy contributions for low vibrational frequencies $(<50$ $\left.\mathrm{cm}^{-1}\right)$ were ignored from the free energies in model $2\left(\Delta \mathrm{G}_{\text {vibr }}{ }^{\ddagger}\right)$. These two different free energies of activation for hydrogen atom abstraction from the $\alpha$ - and aldehyde $\mathrm{C}-\mathrm{H}$ positions are given in the Table in Figure 3. As can be seen from Figure 3, the two barriers $\left({ }^{5} \mathbf{T S}_{\mathrm{HA} \text {,ald }}\right.$ and $\left.{ }^{5} \mathbf{T S}_{\mathrm{HA}, \alpha}\right)$ are within $1 \mathrm{kcal} \mathrm{mol}^{-1}$ from each other and dependent on the model and calculation procedure (see Supporting Information for a detailed comparison of different methods and basis sets) either ${ }^{5} \mathbf{T} \mathbf{S}_{\mathrm{HA}, \alpha}$ or ${ }^{5} \mathbf{T} \mathbf{S}_{\mathrm{HA}, \text { ald }}$ is lower in energy. Within transition state theory, the experimental rate constant of $6.4 \times 10^{-2} \mathrm{M}^{-1} \mathrm{~s}^{-1}$ would correspond to a free energy of activation of $18.4 \mathrm{kcal} \mathrm{mol}^{-1}$. Therefore, our computed barriers with vibrational corrections included are in excellent agreement with the experimental values and also predict the correct regioselectivity.

With vibrational corrections applied, the lowest free energy of activation is via ${ }^{5} \mathbf{T S}_{\mathrm{HA}, \alpha}$ with a $\Delta \mathrm{G}_{\alpha, \text { vibr }}^{\ddagger}=18.1 \mathrm{kcal} \mathrm{mol}^{-1}$, while the aldehyde hydrogen atom abstraction is $\Delta \mathrm{G}^{\ddagger}$ ald,vibr $=18.6 \mathrm{kcal}$ $\mathrm{mol}^{-1}$. As such, the calculations reproduce the experimental product distributions and predict regioselective hydrogen atom abstraction of the $\mathrm{C}^{\alpha}-\mathrm{H}$ bond. Although the Wertz-corrected free energies point to a reversed regioselectivity, actually upon deuteration of the $\mathrm{C}^{\alpha}-\mathrm{H}$ group both models predict a rise of ${ }^{5} \mathbf{T S}_{\mathrm{HA}, \alpha}$ by about $1 \mathrm{kcal} \mathrm{mol}^{-1}$, while the ${ }^{5} \mathbf{T} \mathbf{S}_{\mathrm{HA}, \text { ald }}$ barrier drops slightly. As a consequence, singly deuteration of the $\mathrm{C}^{\alpha}-\mathrm{H}$ group results in a regioselectivity switch from $\mathrm{C}^{\alpha}-\mathrm{H}$ hydrogen atom abstraction to aldehyde hydrogen atom abstraction. On the other hand, deuteration of the aldehyde position of substrate raises the ${ }^{5} \mathbf{T} \mathbf{S}_{\mathrm{HA}, \text { ald }}$ barriers, but keeps the ${ }^{5} \mathbf{T} \mathbf{S}_{\mathrm{HA}, \alpha}$ barriers more or less the same. The computational trends, therefore, are in agreement with experimental observation and implicate a regioselectivity switch upon deuteration of the $\alpha$-position of CCA substrate. As reasoned before, ${ }^{[15]}$ a HAT reaction has a large zero-point energy due to the loss of one $\mathrm{C}-\mathrm{H}$ vibration in the complex. In general, HAT barriers increase in energy by a few $\mathrm{kcal} \mathrm{mol}^{-1}$ upon deuteration of the transferring hydrogen atom. ${ }^{[16]}$ Thus, with two competing barriers very close in energy, substrate 
deuteration raises the lowest barrier in energy and leads to a regioselectivity switch.

As shown before, hydrogen atom abstraction reactions often have barriers that correlate with the strength of the $\mathrm{C}-\mathrm{H}$ bond that is broken in the process. ${ }^{[17]}$ Therefore, we calculated the $\mathrm{C}$ $\mathrm{H}$ bond dissociation energy (BDE) of the $\mathrm{C}^{\alpha}-\mathrm{H}$ and $\mathrm{C}_{\text {aldehyde }}-\mathrm{H}$ bonds from the energy of the substrate with respect to an isolated hydrogen atom and the substrate radical and find values of $\Delta \mathrm{G}=72.1$ and $79.5 \mathrm{kcal} \mathrm{mol}^{-1}$. Based on these values, the reaction should give dominant hydrogen atom abstraction from the $\mathrm{C}^{\alpha}-\mathrm{H}$ bond as seen for the natural substrate. The reason the

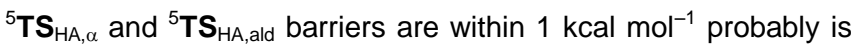
due to electrostatic repulsions between the $\mathrm{L}^{1}$ ligand protons and those from the approaching substrate that are stronger in ${ }^{5} \mathbf{T S}_{\mathrm{HA}, \alpha}$ than in ${ }^{5} \mathbf{T} \mathbf{S}_{\mathrm{HA} \text {,ald }}$, where the cyclohexane ring is further away from the ligand structure.

In summary, a Mn(III)-peroxo complex bearing a pentadentate bispidine backbone was synthesized and characterized with various spectroscopic techniques and studied with DFT. We demonstrate here for the first time that the $\mathrm{Mn}(\mathrm{III})$-peroxo complex is capable of performing electrophilic oxidation of substrates through the hydrogen atom abstraction from the $\mathrm{C}-\mathrm{H}$ bond of an aldehyde to gives the corresponding acid as a product.

\section{Experimental Section}

Experimental Details see Supporting Information.

Keywords: Nonheme $\cdot$ Biomimetic models $\cdot$ Kinetic isotope effects • Oxidation Reaction • Hydrogen atom abstraction • Density functional theory

[1] a) Cytochrome P450: Structure, Mechanism, and Biochemistry, $3^{\text {rd }}$ ed. (Ed.: P. R. Ortiz de Montellano), Kluwer Academic/Plenum Publishers, New York, 2005; b) Biomimetic Oxidations Catalyzed by Transition Metal Complexes (Ed.: B. Meunier), Imperial College Press, London, 2000.

[2] a) M. Costas, M. P. Mehn, M. P. Jensen, L. Que Jr., Chem. Rev. 2004, 104, 939-986; b) C. Krebs, D. G. Fujimori, C. T. Walsh, J. M. Bollinger Jr., Acc. Chem. Res. 2007, 40, 484-492; c) E. I. Solomon, K. M. Light, L. V. Liu, M. Srnec, S. D. Wong, Acc. Chem. Res. 2013, 46, 2725-2739.

[3] a) A. F. Miller, Acc. Chem. Res. 2008, 41, 501-510; b) R. Eisenberg, H. B. Gray, Inorg. Chem. 2008, 47, 1697-1699; c) A. J. Wu, J. E. PennerHahn, V. L. Pecoraro, Chem. Rev. 2004, 104, 903-938.

[4] a) S. V. Kryatov, E. V. Rybak-Akimova, S. Schindler, Chem. Rev. 2005, 105, 2175-2226; b) M. M. Abu-Omar, A. Loaiza, N. Hontzeas, Chem. Rev. 2005, 105, 2227-2252; c) W. Nam, Acc. Chem. Res. 2007, 40, 522-531; d) P. C. A. Bruijnincx, G. van Koten, R. J. M. Klein Gebbink, Chem. Soc. Rev. 2008, 37, 2716-2744; e) M. Atanasov, P. Comba, S. Hausberg, B. Martin, Coord. Chem. Rev. 2009, 253, 2306-2314; f) M. Costas, Coord. Chem. Rev. 2011, 255, 2912-2932; g) A. R. McDonald, L. Que Jr., Coord. Chem. Rev. 2013, 257, 414-428; h) P. Saisaha, J. W. de Boer, W. R. Browne, Chem. Soc. Rev. 2013, 42, 2059-2074.

[5] a) G. Roelfes, V. Vrajmasu, K. Chen, R. Y. N. Ho, J.-U. Rohde, C. Zondervan, R. M. la Crois, E. P. Schudde, M. Lutz, A. L. Spek, R. Hage B. L. Feringa, E. Münck, L. Que Jr., .Inorg. Chem 2003, 42, 2639-2653; b) J. Annaraj, Y. Suh, M. S. Seo, S. O. Kim, W. Nam, Chem. Commun 2005, 4529-4531; c) A. Thibon, J.-F. Bartoli, S. Bourcier, F. Banse, Dalton Trans. 2009, 9587-9584; d) A. Mukherjee, M. A. Cranswick, M. Chakrabarti, T. K. Paine, K. Fujisawa, E. Münck, L. Que Jr., Inorg. Chem. 2010, 49, 3618-3628; e) J. Cho, S. Jeon, S. A. Wilson, L. V. Liu, E. A. Kang, J. J. Braymer, M. H. Lim, B. Hedman, K. O. Hodgson, J. S.
Valentine, E. I. Solomon, W. Nam, Nature 2011, 478, 502-505; f) D. F. Leto, S. Chattopadhyaay, V. W. Day, T. A. Jackson, Dalton Trans. 2013, 42, 13014-13025; g) D. Brazzolotto, F. G. Cantú Reinhard, J. SmithJones, M. Retegan, L. Amidani, A. S. Faponle, K. Ray, C. Philouze, S. P. de Visser, M. Gennari, C. Duboc, Angew. Chem. Int. Ed. 2017, 56, 8211-8215.

[6] a) M. K. Coggins, J. A. Kovacs, J. Am. Chem. Soc. 2011, 133, 12470 12473; b) J. Cho, R. Sarangi, W. Nam, Acc. Chem. Res. 2012, 45 1321-1330; c) M. K. Coggins, V. Martin-Diaconescu, S. DeBeer, J. A. Kovacs, J. Am. Chem. Soc. 2013, 135, 4260-4272; d) H. E. Colmer, A W. Howcroft, T. A. Jackson, Inorg. Chem. 2016, 55, 2055-2069; e) Q. Zhang, A. Bell-Taylor, F. M. Bronston, J. D. Gorden, C. R. Goldsmith, Inorg. Chem. 2017, 56, 773-782.

[7] a) R. B. VanAtta, C. E. Strouse, L. K. Hanson, J. S. Valentine, J. Am. Chem. Soc.1987, 109, 1425-1434; b) N. Kitajima, H. Komatsuzaki, S. Hikichi, M. Osawa, Y. Moro-Oka, J. Am. Chem. Soc.1994, 116, 1159611597 ; c) M. S. Seo, J. Y. Kim, J. Annaraj, Y. Kim, Y.-M. Lee, S.-J. Kim, J. Kim, W. Nam, Angew. Chem. Int. Ed. 2007, 46, 377-380; d) R. A. Geiger, S. Chattopadhyay, V. W. Day, T. A. Jackson, Dalton Trans. 2011, 40, 1707-1715.

[8] A. Shokri, L. Que, Jr., J. Am. Chem. Soc. 2015, 137, 7686-7691.

[9] a) P. Barman, P. Upadhyay, A. S. Faponle, J. Kumar, S. S. Nag, D. Kumar, C. V. Sastri, S. P. de Visser, Angew. Chem. Int. Ed. 2016, 55, 11091-11095; b) F. G. C. Reinhard, P. Barman, G. Mukherjee, J. Kumar, D. Kumar, D. Kumar, C. V. Sastri, S. P. de Visser, J. Am. Chem. Soc. 2017, 139, 18328-18338.

[10] P. Barman, A. K. Vardhaman, B. Martin, S. J. Wörner, C. V. Sastri, P. Comba, Angew. Chem. Int. Ed. 2015, 54, 2095-2099.

[11] $L^{1}=$ dimethyl-2,4-di(2-pyridyl)3-(pyridin-2-ylmethyl)-7-benzyl-3,7-diazabicyclo[3.3.1] nonan-9-one-1,5-dicarboxylate and $L^{2}=$ dimethyl 2,4-di(2pyridyl)-3-benzyl-7-(pyridin-2-ylmethyl)-3,7-diazabicyclo[3.3.1] nonan-9one-1,5-dicarboxylate).

[12] R. L. Shook, W. A. Gunderson, J. Greaves, J. W. Ziller, M. P. Hendrich, A. S. Borovik, J. Am. Chem. Soc. 2008, 130, 8888-8889.

[13] a) W. J. Song, Y. O. Ryu, R. Song, W. Nam, J. Biol. Inorg. Chem. 2005 10, 294-304; b) S. P. de Visser, Chem. Eur. J. 2006, 12, 8168-8177.

[14] S. Shaik, D. Kumar, S. P. de Visser, J. Am. Chem. Soc. 2008, 130, 10128-10140

[15] S. P. de Visser, F. Ogliaro, P. K. Sharma, S. Shaik, Angew. Chem. Int. Ed. 2002, 41, 1947-1951; Angew. Chem. 2002, 114, 2027-2031.

[16] S. P. de Visser, Chem. Eur. J. 2006, 12, 8168-8177.

[17] F. G. Cantú Reinhard, A. S. Faponle, S. P. de Visser, J. Phys. Chem. A 2016, 120, 9805-9814. 


\section{Entry for the Table of Contents}

Layout 1:

\section{COMMUNICATION}

A combined experimental and computational study gives the first evidence of electrophilic reactivity of a side-on manganese(III)-peroxo complex. Furthermore, isotopic substitution of substrate changes the regioselectivity of the reaction and the product distributions.

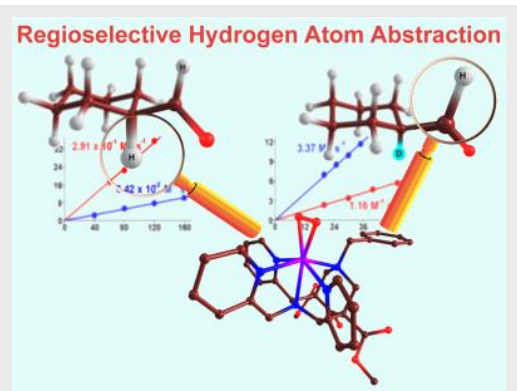

Prasenjit Barman, Fabián G. Cantú Reinhard, Umesh Kumar Bagha,

Devesh Kumar, Chivukula V. Sastri ${ }^{\star}$ and Sam P. de Visser*

Page No. - Page No.

Hydrogen by Deuterium Substitution in an Aldehyde Tunes the Regioselectivity by a Nonheme Manganese(III)-Peroxo Complex 